\title{
Risk factors of early childhood caries among children in Beijing: a case-control study
}

\author{
Cancan Fan ${ }^{\dagger}$, Wenhui Wang ${ }^{\dagger}$, Tao $\mathrm{Xu}^{*}$ and Shuguo Zheng ${ }^{*}$
}

\begin{abstract}
Background: The prevalence of early childhood caries (ECC) among children in Beijing, China, has been increasing continuously though slowly. However, there is limited information about ECC in Beijing. The aim of this study was to identify risk factors of dental caries among preschool children in Beijing.

Methods: For this case-control study, using a convenience sampling method, 787 children aged 3 and 4 years old were recruited; 386 children with caries constituted the early childhood caries (ECC) group and 401children without caries formed the caries-free (CF) group. Dental caries was diagnosed at the tooth surface level by two calibrated examiners according to the WHO 1997 criteria. A structured questionnaire was filled in by the children's main guardians. Mutans streptococci in non stimulated saliva and plaque were measured with the Dentocult SM Strip. Negative binomial regression was used for multivariate analysis.

Results: Analysis of the data showed that level of mutans streptococci in dental plaque and history of dental visit were significantly correlated with the prevalence of caries and the mean dmfs score.

Conclusions: High level of plaque mutans streptococci is a risk factor for ECC in preschool children in Beijing. And longitudinal studies are needed to identify the causal relationships between the levels of mutans streptococci in dental plaque and caries development.
\end{abstract}

Keywords: Early childhood caries, Mutans streptococci, Risk factors

\section{Background}

Although preventive strategies have been implemented for decades, dental caries remains a major problem in both developed and developing countries [1, 2]. The prevalence of early childhood caries (ECC) is especially high in developing countries [3]. Among the possible causes of ECC that have been identified are poor oral hygiene (i.e. visible dental plaque), inadequate tooth brushing, dietary habits (i.e. consumption of sugary snacks and frequency of between-meal snacks), and the presence of specific pathogens $[4,5]$. The risk factors

\footnotetext{
* Correspondence: t-xu@live.com; zhengsg86@gmail.com

Cancan Fan and Wenhui Wang share the first authorship

†Equal contributors

Department of Preventive Dentistry, Peking University School and Hospital of Stomatology, National Engineering Laboratory for Digital and Material Technology of Stomatology, Beijing Key Laboratory of Digital Stomatology, 22 Zhongguancun Avenue SouthHaidian District, Beijing 100081, People's Republic of China
}

(c) 2016 The Author(s). Open Access This article is distributed under the terms of the Creative Commons Attribution 4.0 International License (http://creativecommons.org/licenses/by/4.0/), which permits unrestricted use, distribution, and reproduction in any medium, provided you give appropriate credit to the original author(s) and the source, provide a link to the Creative Commons license, and indicate if changes were made. The Creative Commons Public Domain Dedication waiver (http://creativecommons.org/publicdomain/zero/1.0/) applies to the data made available in this article, unless otherwise stated.

appear to be different in children from different backgrounds [6, 7]. Among these factors, however, mutans streptococci are a common factor that is strongly associated with carious lesions $[8,9]$. Saliva was sampled to measure cariogenic bacteria in most studies, but there are only a few studies that sampled both saliva and plaque simultaneously $[10,11]$.

The prevalence of ECC among children in Beijing has been increasing continuously though slowly. An oral health survey of Beijing residents in 2010 showed that the prevalence of caries among children age groups at 2, 3, 4 and 5 years old were $20,40,55$ and $66 \%$, respectively [12]. A 2005 study reported the prevalence of caries in 5-year-old children was $58.6 \%$ [13]. However, there are few studies on the prevalence and risk factors of ECC in children under 5 years of age in Beijing. Therefore, the aim of this study was to 
investigate the factors associated with ECC in children in Beijing, China.

\section{Methods}

\section{Research design and participants}

The present research is a part of our longitudinal studies of factors related to the incidence and development of ECC in Beijing. This case-control study was conducted in Haidian District of Beijing in 2013. The fluoride concentration in the drinking water is around $0.3-0.4 \mathrm{mgL}$. There is no any systemic use of fluoride in China. All preschool children in kindergartens in Beijing undergo 1.23 \% fluoride foam twice per year. The sample size was estimated according to the prevalence (40\%) of 3-year old children in Beijing reported in 2010 [12]. Therefore, to analyze 17 variables, the total sample size of study children was about 369 using the formula $\mathrm{N}=\mathrm{Z} 2 \times(\mathrm{P} \times(1-\mathrm{P})) / \mathrm{E} 2$, with a margin of error of $5 \%$ and a confidence level of $95 \%$.

A convenience sampling method was used: all 842 children aged 3 and 4 years old from six kindergartens near our hospital were invited to participate in this study. Children who had taken antibiotics within the 2 weeks preceding the examination were conducted a few weeks later. The project was approved by the Human Research Ethics Committee of the School of Stomatology, Peking University, China (PKUSSIRB -2012042).

\section{Oral health questionnaires}

Details regarding the children's demographic status (gender and birth date), nursing feeding habits, sucrose diet habits, oral hygiene practices (brushing frequency, guardians' help, and type of toothpaste), dental visit history, and the guardians' educational level were obtained through a structured questionnaire filled in by the main guardians (Table 1). The questionnaire was simplified from the third national oral health survey in China [14]. Written informed consent for participation in this research was obtained from the guardians of each child included in this study.

\section{Dental examination}

Dental examinations were conducted under a portable light by two calibrated examiners using a CPI (community periodontal index) explorer and a disposable mirror, with a cotton swab to dry the teeth. The child, seated in a small chair, was asked to recline on to the knee of the examiner. Dental caries was diagnosed at the tooth surface level according to the WHO 1997 criteria [15], CPI probe was applied with visual examination in diagnosis. Radiography was not used in this study. The interexaminer kappa value was 0.82 and intra-examiner kappa values for the two examiners were 0.88 and 0.86 . Children were reexamined by two examiners 1 week later for the calculation of intra-examiner kappa values.

\section{Plaque and saliva samples}

Dentocult SM Strip (Orion Diagnostica, Espoo, Finland) was used to evaluate the levels of mutans streptococci in both non stimulated saliva and plaque $[16,17]$. The non stimulated saliva samples were obtained by pressing the rough surface of the strip against the child's tongue and turning it over 10 times. The children were not asked to chew paraffin for salivary stimulation. Four specific sites of dental plaque were sampled: the buccal surfaces of teeth 55,51 , and 71 , and the lingual surface of tooth 75 . Plaque samples were collected by stroking the tooth surface near the gingival margin with a mini-brush; separate brushes were used for each tooth. The brushes with the plaque samples from the four teeth were immediately applied to the four roughened sites on the strip, and the strips were then placed in the culture medium and incubated at $37{ }^{\circ} \mathrm{C}$ for $48 \mathrm{~h}$.

The level of mutans streptococci was scored following the standard provided by the manufacturer. The score " 0 " corresponds to $<10^{4}$ of CFU (colony-forming units)/ $\mathrm{mL}$, "1" to $10^{4}-10^{5}$ of CFU/mL, " 2 " to $10^{5}-10^{6}$ of CFU/ $\mathrm{mL}$, and "3" to $>10^{6}$ of CFU/mL. The scores of all strips were recorded by the same investigator, to whom the results of clinical examination were not available. The highest score of the four sites was recorded as the plaque mutans streptococci level of the child.

\section{Statistical analyses}

The research data included the results of the dental examination, the bacterial scores assessed by the Dentocult SM Strip method, and the information from the questionnaire survey. The chi-square test or Fisher's exact test were used in univariate analyses to assess the differences between the ECC and CF groups. The mean $\mathrm{dmfs}$ scores of children with the same level of mutans streptococci infection were calculated and were compared using the t-test and one-way ANOVA using SPSS Statistics for Windows, version 20.0 (IBM Corp. Armonk, NY, USA). Negative binomial regression was used to identify the variables associated with ECC; SAS software, version 9.3 (SAS Institute, Cary, NC, USA) was used for this analysis. Statistical significance was set at $P<0.05$.

\section{Results \\ Demographics}

In all, 787 children aged between 26 and 57 months (mean age $46.02 \pm 5.59$ ) responded, submitting the filledin questionnaires and undergoing dental examination and laboratory test. Four hundred and twenty-four (53.9 \%) were male. The caries prevalence and mean dmfs score of these children were $49 \%$ and $4.50 \pm 7.92$. These children were separated into two groups: a caries (ECC) group, comprising 386 children with $\mathrm{dmfs} \geq 1$, 
Table 1 Characteristics of participants and results of laboratory tests

\begin{tabular}{|c|c|c|c|c|}
\hline Variables & $\begin{array}{l}\text { ECC group } \\
N(\%)\end{array}$ & $\begin{array}{l}\text { CF group } \\
N(\%)\end{array}$ & Total & $P$ \\
\hline Age (months) & $46.3 \pm 5.43$ & $45.7 \pm 5.73$ & 787 & 0.96 \\
\hline Gender & & & & 0.09 \\
\hline Male & $220(58.0)$ & $204(49.6)$ & 424 & \\
\hline Female & $166(42.0)$ & $197(50.4)$ & 363 & \\
\hline Person filling out the questionnaire & & & & 0.08 \\
\hline Father & $102(26.4)$ & $92(22.9)$ & 194 & \\
\hline Mother & $238(61.7)$ & $267(66.6)$ & 505 & \\
\hline Grandfather/Grandmother & $42(10.9)$ & $40(10.0)$ & 82 & \\
\hline Other (relative/nanny) & $4(1.0)$ & $2(0.5)$ & 6 & \\
\hline Using nursing bottle or not at present & & & & $0.01 *$ \\
\hline Yes & $70(18.2)$ & $102(25.4)$ & 172 & \\
\hline No & $315(81.8)$ & $299(74.6)$ & 614 & \\
\hline Contents of nursing bottle & & & & 0.78 \\
\hline Water or milk & $155(87.1)$ & $152(89.4)$ & 307 & \\
\hline Sugared beverages & $21(12.9)$ & $18(10.6)$ & 39 & \\
\hline Sleeping with nursing bottle & & & & 0.45 \\
\hline Always & $8(4.1)$ & $3(1.5)$ & 11 & \\
\hline Sometimes & $24(12.3)$ & $23(11.3)$ & 47 & \\
\hline Rarely or never & $163(83.6)$ & $178(87.2)$ & 341 & \\
\hline Frequency of snack consumption & & & & $0.03^{*}$ \\
\hline Never or seldom & $22(5.7)$ & $30(7.5)$ & 52 & \\
\hline Sometimes (<1 Times/Day) & $93(24.3)$ & $94(23.5)$ & 187 & \\
\hline 1-2 Times/Day & $166(43.3)$ & $204(50.8)$ & 370 & \\
\hline 3-4 Times/Day & $86(22.5)$ & $65(16.2)$ & 151 & \\
\hline$\geq 5$ Times/Day & $16(4.2)$ & $8(2.0)$ & 24 & \\
\hline Rinsing or brushing teeth after snacks & & & & 0.71 \\
\hline Always & $104(27.1)$ & $114(28.4)$ & 218 & \\
\hline Sometimes & $173(45.2)$ & $183(45.6)$ & 356 & \\
\hline Never or seldom & $106(27.7)$ & $104(26.0)$ & 210 & \\
\hline Sleeping without brushing after snacks & & & & 0.70 \\
\hline Always & $22(5.8)$ & $22(5.5)$ & 44 & \\
\hline Sometimes & $96(25.1)$ & $94(23.5)$ & 190 & \\
\hline Never or seldom & $264(69.1)$ & $284(71.0)$ & 548 & \\
\hline Frequency of tooth brushing & & & & $0.008^{*}$ \\
\hline Twice daily & $185(48.4)$ & $156(39.2)$ & 341 & \\
\hline Once daily & $161(42.2)$ & $176(44.2)$ & 337 & \\
\hline Less than once daily & $32(8.4)$ & $58(14.6)$ & 90 & \\
\hline Never & $4(1.0)$ & $8(2.0)$ & 12 & \\
\hline Guardians helping with the brushing & & & & 0.23 \\
\hline Everyday & $116(30.4)$ & $97(24.4)$ & 213 & \\
\hline Sometimes & $137(35.9)$ & $144(36.2)$ & 281 & \\
\hline No or never brushing & $129(33.7)$ & 157 (39.4) & 286 & \\
\hline
\end{tabular}


Table 1 Characteristics of participants and results of laboratory tests (Continued)

\begin{tabular}{|c|c|c|c|c|}
\hline Toothpaste containing fluoride & & & & 0.27 \\
\hline Yes & $151(39.8)$ & $136(34.7)$ & 287 & \\
\hline No & $122(32.2)$ & $127(32.4)$ & 249 & \\
\hline Not sure & $87(23.0)$ & $99(25.3)$ & 186 & \\
\hline Not having used toothpaste & $19(5.0)$ & $30(7.6)$ & 49 & \\
\hline Dental visit history & & & & $<0.001^{* *}$ \\
\hline Yes & $279(73.2)$ & $121(30.4)$ & 400 & \\
\hline No & $102(26.8)$ & $277(69.6)$ & 379 & \\
\hline Education level of person filling out the questionnaire & & & & 0.07 \\
\hline Junior high school & $6(1.6)$ & $10(2.5)$ & 16 & \\
\hline Senior high school & $104(27.3)$ & $87(21.8)$ & 192 & \\
\hline College and above & $271(71.1)$ & $303(75.7)$ & 576 & \\
\hline MS score of saliva & & & & $<0.001^{* *}$ \\
\hline $0\left(\mathrm{CFU}<10^{4}\right)$ & $152(39.4)$ & $306(76.3)$ & 458 & \\
\hline $1\left(\mathrm{CFU} 10^{4}-10^{5}\right)$ & $67(17.4)$ & $50(12.5)$ & 117 & \\
\hline $2\left(\mathrm{CFU} 10^{5}-10^{6}\right)$ & $124(32.1)$ & $39(9.7)$ & 163 & \\
\hline $3\left(\mathrm{CFU}>10^{6}\right)$ & $43(11.1)$ & $6(1.5)$ & 49 & \\
\hline MS score of plaque & & & & $<0.001^{* *}$ \\
\hline $0\left(\mathrm{CFU}<10^{4}\right)$ & $80(20.7)$ & $243(60.6)$ & 323 & \\
\hline $1\left(\mathrm{CFU} 10^{4}-10^{5}\right)$ & $16(4.2)$ & $19(4.7)$ & 35 & \\
\hline $2\left(\mathrm{CFU} 10^{5}-10^{6}\right)$ & $34(8.8)$ & $39(9.7)$ & 73 & \\
\hline $3\left(\mathrm{CFU}>10^{6}\right)$ & $256(66.3)$ & $100(25)$ & 356 & \\
\hline
\end{tabular}

MS mutans streptococci

*Significant at $P<0.05 ;{ }^{*}$ Significant at $P<0.001$

and a caries-free (CF) group, comprising 401 children without visible diagnosed caries.

\section{Univariate analyses results}

The information obtained through the questionnaire and the scores for mutans streptococci infection in the two groups are presented in Table 1 . Six variables, i.e., use of nursing bottle or not at present $(P=0.01)$, frequency of snacks consumption $(P=0.03)$, Frequency of tooth brushing $(P=0.008)$, dental visit history $(P<0.001)$, plaque mutans streptococci level $(P<0.001)$, and salivary mutans streptococci $(P<0.001)$ were associated with dental caries by univariate analyses.

In the ECC group, $60.6 \%$ of children scored $\geq 1$ for salivary mutans streptococci, compared to $23.7 \%$ in the CF group; for plaque mutans streptococci, $79.3 \%$ scored $\geq 1$ in the ECC group vs. $39.4 \%$ in the CF group.

\section{Negative binomial regression test}

Of the six variables that were found to be significantly associated with caries in univariate analysis, only mutans streptococci in plaque and dental visit history retained statistically significant association with dental caries on multivariate analysis (Table 2).
Children with a score of " 3 " for plaque mutans streptococci (i.e., high level of infection) had 1.97 greater odds of having caries than those who scored "0" (i.e., had low level of infection). Children who had history of dental visit had 1.93 greater odds of having dental caries than children who had not visited a dentist.

Among CF children, a large proportion (60.6\%) had low levels of plaque mutans streptococci (i.e., score $=0$ ), whereas, among ECC children a large proportion (66.3 \%) had high level of plaque infection (i.e., score $=3$ ). The prevalence of caries and the mean dmfs score were higher in children with more plaque mutans streptococci (Table 3).

\section{Discussion}

To our knowledge, this is the first study on the risk factors of ECC in China that has measured mutans streptococci levels in both non stimulated saliva and plaque $[2,18-20]$. It is also the first study in China to use the Dentocult SM Strip, a practical and readily used semi-quantitative method, to measure plaque mutans streptococci [21], though a few studies have used this method in other countries [22, 23]. 
Table 2 Results of negative binomial regression for dmfs index among preschool children in Beijing

\begin{tabular}{|c|c|c|c|}
\hline Variables & Negative binomial coefficients (95\% Cl) & Wald $\times 2$ & $P$ \\
\hline Intercept & $-0.67(-1.79,0.46)$ & 1.35 & 0.24 \\
\hline \multicolumn{4}{|l|}{ Use of nursing bottle at present } \\
\hline Yes & $-0.06(-0.33,0.21)$ & 0.20 & 0.65 \\
\hline No & -—- & -—- & -—- \\
\hline \multicolumn{4}{|l|}{ Frequency of snack consumption } \\
\hline Never or seldom & $-0.23(-0.90,0.43)$ & 0.47 & 0.50 \\
\hline Sometimes (<1 Times/Day) & $-0.13(-0.67,0.41)$ & 0.22 & 0.63 \\
\hline 1-2 Times/Day & $-0.24(-0.76,0.28)$ & 0.82 & 0.37 \\
\hline 3-4 Times/Day & $-0.09(-0.63,0.45)$ & 0.11 & 0.74 \\
\hline$\geq 5$ Times/Day & -—- & -—- & -—- \\
\hline \multicolumn{4}{|l|}{ Frequency of tooth brushing } \\
\hline Twice daily & $0.10(-0.90,1.11)$ & 0.04 & 0.84 \\
\hline Once daily & $0.11(-0.90,1.11)$ & 0.04 & 0.84 \\
\hline Less than once daily & $-0.07(-1.11,0.98)$ & 0.02 & 0.90 \\
\hline Never & -— & -— & -— \\
\hline \multicolumn{4}{|l|}{ Dental visit history } \\
\hline Yes & $0.73(0.49,0.97)$ & 34.13 & $<0.001^{*}$ \\
\hline No & -—- & -—- & -—- \\
\hline \multicolumn{4}{|l|}{ MS score in plaque } \\
\hline $0\left(\mathrm{CFU}<10^{4}\right)$ & $-0.77(-1.13,-0.42)$ & 18.07 & $<0.001^{*}$ \\
\hline $1\left(\right.$ CFU $\left.10^{4}-10^{5}\right)$ & $-0.16(-0.71,0.38)$ & 0.35 & 0.55 \\
\hline $2\left(\mathrm{CFU} 10^{5}-10^{6}\right)$ & $-0.31(-0.70,0.09)$ & 2.29 & 0.13 \\
\hline $3\left(\mathrm{CFU}>10^{6}\right)$ & -— & -—- & -— \\
\hline \multicolumn{4}{|l|}{ MS score in saliva } \\
\hline $0\left(\mathrm{CFU}<10^{4}\right)$ & $-0.22(-0.63,0.19)$ & 1.11 & 0.29 \\
\hline 1 (CFU $10^{4}-10^{5}$ ) & $-0.19(-0.60,0.21)$ & 0.90 & 0.34 \\
\hline $2\left(\mathrm{CFU} 10^{5}-10^{6}\right)$ & $-0.03(-0.39,0.33)$ & 0.03 & 0.87 \\
\hline $3\left(\mathrm{CFU}>10^{6}\right)$ & -—- & --- & -—- \\
\hline
\end{tabular}

MS mutans streptococci

*Significant at $P<0.001$

Previous studies have shown that mutans streptococci are strongly associated with dental caries [11, 24]. Vachirarojpisan, et al. [25] found that mutans streptococci level in non stimulated saliva was the only statistically significant indicator of ECC among various variables, which included family income, breast feeding, education level and decayed teeth of caregivers in children aged 6-19 months. Research has also shown that children with caries have higher levels of Streptococcus mutans and Streptococcus sobrinus in children' dental plaque [26]. Researchers using PCR have reported a negative association between Streptococcus mutans and caries, and instead found

Table 3 Prevalence of caries and mean dmfs scores for children with different levels of plaque mutans streptococci

\begin{tabular}{|c|c|c|c|}
\hline PMS & $\mathbf{N}$ & Prevalence (\%) & dmfs (mean \pm SD) \\
\hline 0 & 323 & 24.8 & $1.15 \pm 3.20 \Longrightarrow$ \\
\hline 1 & 35 & 45.7 & $3.02 \pm 4.65$ \\
\hline 2 & 73 & T $* *$ & $3.15 \pm 5.23=* *$ \\
\hline 3 & 356 & 71.9 & $7.96 \pm 9.97 \Longrightarrow$ \\
\hline
\end{tabular}


Lactobacillus fermentum to be associated with ECC [27], indicating that caries is a progressive disease that may be associated with many different caries-causing microorganisms in the course of its development [19].

Many previous studies that reported a positive association between caries and mutans streptococci infection used saliva samples to assess bacterial levels because of the clinical convenience [24, 25]. Some studies also reported that high levels of mutans streptococci and lactobacillus in saliva act synergistically to increase the $\mathrm{dmfs}$ index [28]. In our study, both saliva and plaque samples were used to estimate mutans streptococci infection. The results showed that plaque mutans streptococci levels had much stronger correlation with ECC than that in saliva. The positive association that we found between ECC and salivary mutans streptococci level in univariate analysis disappeared on multivariate analysis. Theoretically, plaque is more appropriate for estimating mutans streptococci infection in individuals because tooth surfaces are the natural habitat of this organism [29]. Furthermore, it has been demonstrated that in children aged 9-36 months, the values for mutans streptococci in the dental biofilm are significantly higher than those found in tongue samples [30]. The results of this study are consistent with these previous studies, showing that plaque mutans streptococci levels are superior to salivary levels for indicating risk of ECC among children in Beijing [8].

More than $70 \%$ of the ECC children in this study had dental visit history. Other studies also found higher caries prevalence in children who had visited a dentist $[1,31]$. The results of this study suggest that most children visit a dentist only after caries were developed. Parents need to seek preventive care for their children and not just consult the dentist after problems arise.

This study has a few limitations. The WHO diagnostic criteria haven't included the white spot, and no radiograph was used for diagnosis of proximal caries, thus may underestimate the associations between caries and risk factors. Jin et al. recommended that both noncavitated and cavitated carious lesions should be included in the diagnostic criteria for research of dental caries in primary teeth [32].

The convenience sample selected from an urban area may not represent the overall condition in Beijing. We compared the prevalence of caries in this study (49.0\%) and that of a large-scale survey (46.6\%) containing 226165 3-4-year-old children of Beijing [33], and there was no significant difference. The results of this study are applicable only to other population with similar social background and demographics. Some possible risk factors such as maternal oral health status and enamel hypoplasia were not assessed. In addition, the crosssectional nature of this study meant that we could only identify correlation between risk factors and caries. A longitudinal study will be necessary to identify and better understand the predictors of ECC.

\section{Conclusion}

In conclusion, this study demonstrates that a high level of mutans streptococci in plaque appears to be a risk factor for ECC in Beijing, China. The plaque level of mutans streptococci is more representative of oral infection and more closely associated with ECC than the non stimulated salivary levels. A longitudinal study is needed to identify any causal relationship between plaque mutans streptococci and ECC in children in Beijing, for it is crucial to screen preschool children at high risk of developing caries.

\section{Abbreviations \\ CF: Caries-free; dmfs: Decayed, missing, and filled surfaces; ECC: Early childhood caries}

\section{Acknowledgements}

The authors would like to thank the children and the guardians for their cooperation, and thank the teachers in the kindergartens for their assistance.

Funding

Peking University School and Hospital of Stomatology (PKUSS20120204).

\section{Availability of data and materials}

The datasets generated during the current study are not publicly available due to the unfinished data analysis of longitudinal study, but are available from the corresponding author on reasonable request.

\section{Authors' contributions}

CF participated in the study design, contributed to the epidemiological data collection and analyses, drafted the manuscript. WW designed the study, the main investigator who examined the children and revised the manuscript. TX and SZ the supervisors, provided valuable guidance in study design and editorial review. All authors read and approved the final manuscript.

\section{Competing interests}

The authors declare that they have no competing interests.

\section{Consent for publication}

This manuscript was not involved with details, images, or videos relating to individual participants. Written informed consent of this research was obtained from the guardians of participants.

Ethics approval and consent to participate

The project was approved by the Human Research Ethics Committee of the School of Stomatology, Peking University, China (PKUSSIRB -2012042).

Written informed consent for participation in this research was obtained from the guardians of each child included in this study.

Received: 18 May 2016 Accepted: 25 August 2016

Published online: 17 September 2016

References

1. Nobile CG, Fortunato L, Bianco A, Pileggi C, Pavia M. Pattern and severity of early childhood caries in Southern Italy: a preschool-based cross-sectional study. BMC Public Health. 2014;14:206.

2. Zhou Y, Lin HC, Lo ECM, Wong MCM. Risk indicators for early childhood caries in 2-year-old children in southern China. Aust Dent J. 2011;56:33-9.

3. Carino KM, Shinada K, Kawaguchi Y. Early childhood caries in northern Philippines. Community Dent Oral Epidemiol. 2003;3:81-9.

4. Han DH, Kim DH, Kim MJ, Kim JB, Jung-Choi K, Bae KH. Regular dental checkup and snack-soda drink consumption of preschool children are associated with early childhood caries in Korean caregiver/preschool children dyads. Community Dent Oral Epidemiol. 2014;42:70-8. 
5. Quinonez RB, Keels MA, Vann Jr WF, Mclver FT, Heller K, Whitt JK. Early childhood caries: analysis of psychosocial and biological factors in a high-risk population. Caries Res. 2001;35:376-83.

6. Wulaerhan J, Abudureyimu A, Bao XL, Zhao J. Risk determinants associated with early childhood caries in Uygur children: a preschool-based cross-sectional study. BMC Oral Health. 2014;14:136. doi:10.1186/1472-6831-14-136.

7. Vanobbergen J, Martens L, Lesaffre E, Bogaerts K, Declerck D. Assessing risk indicators for dental caries in the primary dentition. Community Dent Oral Epidemiol. 2001;29:424-34.

8. Tanzer JM, Livingston J, Thompson AM. The microbiology of primary dental caries in humans. J Dent Educ. 2001;65:1028-37.

9. Palmer CA, Kent Jr R, Loo CY, Hughes CV, Stutius E, Pradhan N, et al. Diet and caries-associated bacteria in severe early childhood caries. J Dent Res. 2010;89:1224-9.

10. Matee MIN, Mikx FHM, Maselle SYM, Van Palenstein Helderman WH. Mutans streptococci and lactobacilli in breastfed children with rampant caries. Caries Res. 1992:26:183-7.

11. Seki M, Karakama F, Terajima T, Ichikawa Y, Ozaki T, Yoshida S, et al. Evaluation of mutans streptococci in plaque and saliva: correlation with caries development in preschool children. J Dent. 2003;31:283-90.

12. People's Government of Beijing Municipality. The report of hygiene and population health condition of Beijing in 2010. Beijing: People's Medical Publishing House. 2010;25-26:69 (In Chinese).

13. Zhang H, Han Y, Hou W, Zhu M, Yi X, Wu D. A survey of primary teeth caries among 5-year-old children in Beijing. Beijing J Stomatol. 2009;17: 109-12 (In Chinese).

14. Qi X. The third national oral health survey. China: People's Medical Publishing House; 2008. p. 218-22 (In Chinese).

15. World Health Organization. Oral health surveys: basic methods 4th edn. Geneva: World Health Organization; 1997.

16. Jensen $B$, Bratthall D. A new method for the estimation of mutans streptococci in human saliva. J Dent Res. 1989:68:468-71.

17. Bratthall D, Hoszek A, Zhao XM. Evaluation of a simplified method for site-specific determination of mutans streptococci levels. Swed Dent J. 1996;20:215-20.

18. Qin M, Li J, Zhang S, Ma W. Risk factors for severe early childhood caries in children younger than 4 years old in Beijing, China. Pediatr Dent. 2008;30: $122-8$.

19. Hao W, Xu H, Chen X, Zhou Q, Zhang P, Chen F, et al. Changes in dental plaque microbial richness and oral behavioral habits during caries development in Young Chinese Children. Caries Res. 2015;49:116-23.

20. Chen L, Mao T, Du M, Yang Y, Xu Q, Fan M. Caries status and quantification of four bacteria in saliva of Chinese preschool children: a cross-sectional study. J Dent Sci. 2014;9:283-8.

21. Shi S, Deng Q, Hayashi Y, Yakushiji M, Machida Y, Liang Q. A follow-up study on three caries activity tests. J Clin Pediatr Dent. 2003;27:359-64.

22. Ramamurthy $\mathrm{PH}$, Swamy HS, Bennete F, Rohini M, Nagarathnamma T. Relationship between severe-early childhood caries, salivary mutans streptococci, and lactobacilli in preschool children of low socioeconomic status in Bengaluru city. J Indian Soc Pedod Prev Dent. 2014;32:44-7.

23. ElSalhy M, Honkala S, Soderling E, Varghese A, Honkala E. Relationship between daily habits, streptococcus mutans, and caries among schoolboys. J Dent. 2013:41:1000-6.

24. Parisotto TM, Steiner-Oliveira C, Silva CM, Rodrigues LK, Nobre-dos-Santos M. Early childhood caries and mutans streptococci: a systematic review. Oral Health Prev Dent. 2010;8:59-70.

25 Vachirarojpisan T, Shinada K, Kawaguchi Y, Laungwechakan P, Somkote T, Detsomboonrat P. Early childhood caries in children aged 6-19 months. Community Dent Oral Epidemiol. 2004;32:133-42.

26 Mitrakul K, Vongsavan K, Suratanachaikul P. Prevalence of Streptococcus mutans and Lactobacillus fermentum and their association with caries and dietary habits in preschool Thai children. Eur Arch Paediatr Dent. 2013;14:83-7.

27 Leong PM, Gussy MG, Barrow SL, de Silva-Sanigorski A, Waters E. A systematic review of risk factors during first year of life for early childhood caries. Int J Paediatr Dent. 2013;23:235-50

28 Karaoğlanoğlu S, Akgül N, Akgül HM. The association between the DMFS index and levels of salivary Streptococcus mutans and lactobacilli of subjects living in Erzurum, Turkey. J Dent Sci. 2010;5:70-4.

29 Alaluusua S, Renkonen OV. Streptococcus mutans establishment and dental caries experience in children from 2 to 4 years old. Scand J Dent Res. 1983; 91:453-7.
30 Barsamian-Wunsch P, Park JH, Watson MR, Tinanoff N, Minah GE. Microbiological screening for cariogenic bacteria in children 9 to 36 months of age. Pediatr Dent. 2004;26:231-9.

31 Nunn ME, Dietrich T, Singh HK, Henshaw MM, Kressin NR. Prevalence of early childhood caries among very young Urban Boston children compared with US Children. J Public Health Dent. 2009;69:156-62.

32 Jin BH, Ma DS, Moon HS, Paik DI, Hahn SH, Horowitz AM. Early childhood caries: prevalence and risk factors in Seoul, Korea. J Public Health Dent. 2003:63:183-8.

33 Liu M, Shi Y, Wang P, Han Y, Zhang H. A survey of the early childhood caries in 3-5 years children in Beijing 2013. Beijing J Stomatol. 2015;23: 282-7 (In Chinese)

\section{Submit your next manuscript to BioMed Central and we will help you at every step:}

- We accept pre-submission inquiries

- Our selector tool helps you to find the most relevant journal

- We provide round the clock customer support

- Convenient online submission

- Thorough peer review

- Inclusion in PubMed and all major indexing services

- Maximum visibility for your research

Submit your manuscript at www.biomedcentral.com/submit
) Biomed Central 